\title{
Concrete passions: Anscombe's material politics
}

Christine McCarthy, Interior Architecture Programme, School of Architecture, Victoria University, Wellington

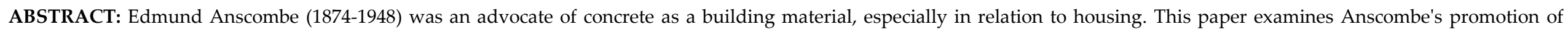

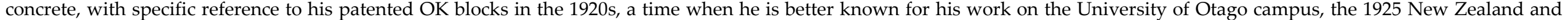
South Seas Exhibition, and his move from Dunedin to Wellington in 1928.

\section{Introduction}

"Why, Oh Why, do men erect factories and office buildings as fireproof as their office safe; protect the lives of their employees by every known device; guard their business records and material at any cost; AND at

the same time house their family in dwellings as inflammable as kindling?"

(The House Everlasting: Homes Constructed with O.K. Building Blocks (1921) p. [17])

In September 1918, Edmund Anscombe applied for a letter patent for two inventions: a hollow-wall construction (no. 40562), and for concrete floor and roof construction (no. 40563). ${ }^{1}$ These applications were sealed in March 1920. That same year he applied for patents for concrete-block manufacture (44081), and a concrete-block-making machine

1 "Applicants for Letter Patent for Inventions for the Year 1918" New Zealand Patent Office (5 September 1918) p 368; "Applicants for Letter Patent for Inventions for the Year 1918" New Zealand Patent Office (19 September 1918) p 395; "Patents Sealed" p 105. see also "Building Construction" pp 751-752.
(44217), both sealed the next year, 1921. ${ }^{2}$ These patents described Anscombe's OK Dry Wall System, with which he had built his house Cintra, 217 Musselburgh Rise, Dunedin (1919). ${ }^{3}$ Anscombe's block system involved 14 different block types (from A to N) in order to accommodate the idiosyncrasies of building: from foundations, ventilation grids, and corners, to the reveals of window openings. The blocks were rectilinear, the majority of them about half the thickness of conventional concrete blocks. The outer surface of the regular block (Block G: $17^{3} / 4^{\prime \prime}$ x 83/4" x 2") was flat, while the inner surface was moulded to minimise the material of the block (down to a thinness of 1"), ${ }^{4}$ and to provide a "nib" (which

2 "Alphabetical List of Applicants for Letters Patent for Inventions for the Year 1921" p 52.

${ }^{3}$ The House Everlasting cover photograph, Anscombe

"The history of the OK. Dry Wall System of Building Construction" p 1.

${ }^{4}$ Rice notes "the desirability of providing a large hollow space by making face-sections as thin as consistent with safety." Rice Concrete-Block Manufacture p 6. the New Zealand Building Progress described as "stiffeners"), ${ }^{5}$ which, in the built wall, formed "4in studs arranged alternately at 9in intervals, which become continuous."6 The blocks formed one side of a continuous cavity wall which was tied to its other half by a series of No. 10 wire Bonding Ties. ${ }^{7}$ The size and shape of the blocks meant they were lighter, easier to make, and easier to handle than contemporary block types.

Concrete blocks at this time were not new in New Zealand, nor internationally. Thornton notes that:

The first patent for concrete blocks (presumably solid) was issued in 1875 in England. It seems that concrete blocks imitating masonry were in use in the United States from 1868 when one Greary patented his design. ... In his Building Materials of Otago, published in 1870, W.N. Blair states that in England concrete blocks were made in large quantities by machinery for arch-stones,

\footnotetext{
5 "Building Construction" p 752.

${ }^{6}$ The House Everlasting p 2.

7 The House Everlasting p 13.
} 
quoins, sills, lintels, steps and mouldings of all kinds but not for general building. ${ }^{8}$

Simpson et al. identify the "mass production of hollow concrete blocks" as a twentiethcentury phenomenon, ${ }^{9}$ crediting Harmon S Palmer's invention of a cast iron block machine (patented in 1899) as the beginning of the modern industry. ${ }^{10}$ They note that "[t]he growth in popularity of concrete block in the first two decades of the twentieth century was phenomenal,"11 but also state that prior to 1915, "nearly 75 percent were used for foundation and basement walls or as partition walls." ${ }^{2}$ Thornton refers to an October 1906 article in NZ Building Progress that noted that:

"rapid progress has been made over the past five years with a new material - the hollow concrete block ... the

\footnotetext{
${ }^{8}$ Thornton Cast in Concrete $\mathrm{p}$ 123. Rice lists James Gibbs as having registered a patent which had "important bearing on the subject of concrete blocks" in 1850 (British Patent No. 13071) Rice The manufacture of concrete blocks $p$ 48. He lists the following American patents for hollow core concrete blocks prior to HS Palmer: TJ Lowry no. 80358 (1868), Theodore Hyatt no. 142475 (1873) and TB Rhodes 149678 (1874).

9 Simpson et al. "Concrete Block" p 80

${ }^{10}$ Simpson et al. "Concrete Block" p 80. Simpson et al. refer to 1900 as the date of the patent, whereas Isaacs refers to 1899. Isaacs "Concrete Blocks" p 86.

11 Simpson et al. "Concrete Block" p 80.

${ }^{12}$ Simpson et al. "Concrete Block" p 83.
}

industry has grown almost as surprisingly as the manufacture of Portland cement." These blocks were practically unknown in 1900, Progress continued: "but it is probably safe to say that at present more than 2,000 companies and individuals are engaged in their manufacture in the U.S. and the United Kingdom. The cause in the U.S. is the rapidly failing lumber supply and the widespread interest in all applications of Portland cement." There is no mention of any New Zealand use of such blocks. ${ }^{13}$

Simpson et al. identify key issues as: the availability of "an improved and reliable portland cement," debate regarding ornamental faces, improvements in "machines, mixtures and curing methods," the introduction of lightweight aggregates, and testing for reliability and durability. ${ }^{14}$ By the time Anscombe submitted his patent applications, concrete producer associations were being formed, and block sizes were in the process of being standardised. Standard block sizes were agreed to in $1924 .{ }^{15}$ Blocks were advertised as cheaper, faster to install, fireproof, and low maintenance. ${ }^{16}$

\footnotetext{
${ }^{13}$ New Zealand Building Progress quoted, Thornton, Cast in Concrete pp 122-123.

${ }^{14}$ Simpson et al. "Concrete Block" pp 80, 82.

${ }^{15}$ Simpson et al. "Concrete Block" p 80.

${ }^{16}$ Simpson et al. "Concrete Block" p 83.
}

New Zealand's first use of concrete blocks in architecture appears to have been in the late nineteenth century. Thornton refers to the Burgess Island lighthouse, Mokohinau as being made from purpose-made concrete blocks in $1882,{ }^{17}$ and the lining of the $135 \mathrm{~km}$ long Kahatu Tunnel No. 1 in concrete blocks in $1893 .{ }^{18}$ Isaacs refers to New Zealand uptake of Palmer's machine as early as 1904, with Niels Nielsen's Wellington Hollow Concrete Building Block Company supplying blocks for a warehouse on Tory St, and houses near their factory in Lyall Bay, and a five bedroom house in Oriental Bay dated c1904. ${ }^{19}$ In 1908, concrete blocks (specifically John Mitchell's SPD System of Building) were investigated by the government as a possible solution to the vulnerability of railway buildings to fire. ${ }^{20}$ Concrete blocks were made in Cambridge, Napier, Timaru, Westport, and Whangarei by 1910. ${ }^{21}$ Invercargill prison also installed a "concrete-block making plant" soon after it was built, in 1908-10.22 Two Prison Branch files, titled: "Manufacturing concrete blocks -

\footnotetext{
17 Thornton Cast in Concrete p 71.

${ }^{18}$ Thornton Cast in Concrete pp 92, 193.

${ }^{19}$ Isaacs "Concrete Blocks" p 86.

20 "S.P.D. System of Building Construction [pamphlet]."

${ }^{21}$ Isaacs "Concrete Blocks" p 86.
}

${ }^{22}$ Thornton Cast in Concrete p 123. 
Waikeria Borstal" and "Re that all prison residence be built of concrete blocks," suggest that the relationship between concrete blocks and prisons was even more widespread.

Concrete block houses were also built in Invercargill; 223 Ettrick and 109 Earn Streets are two examples. ${ }^{23}$ In 1919, the FE Powelledited Concrete Information: a practical handbook for all classes of concrete users was published for the cement manufacturers of New Zealand. ${ }^{24}$ Later, the 1922 Thompson House (322 Crinan St, Invercargill), and a 1918 Methodist church, Manakau, Manawatu were built of concrete blocks, the church being described by Thornton as "[a]n early use of concrete blocks."25

It is usually assumed that hollow concrete blocks are "blocks containing one or more hollow spaces," but Rice (writing in c1906) also includes "blocks of such shape that their combination in a wall will produce hollow spaces therein,"26 identifying a specific lineage within from Anscombe's blocks derive. These two-piece types originated, according to Rice,

\footnotetext{
${ }^{23}$ Thornton Cast in Concrete pp 120-121, 123.

${ }^{24}$ Isaacs "Concrete Blocks" p 87.

${ }^{25}$ Thornton Cast in Concrete p 159.

${ }^{26}$ Rice Concrete-Block Manufacture $\mathrm{p} 3$.
}

c1902, "with a view of overcoming some of the difficulties of manufacture attendant upon the making of the one-piece blocks, of enabling the operator to follow more closely the recognized standards of good concreting, of enabling the builder to adhere to the principles of the best engineering practice in wall-construction, and of affording a more thorough insulation than that secured by onepiece blocks." ${ }^{27}$ He identifies two-piece block patents owned by the American Hydraulic Stone Co. (no. 704606: patented by CF Whittlesey, July 1902), and Mather and Bowne (no. 776409, November 1904). Other authors referencing this type of block include James ${ }^{28}$ and Palliser, ${ }^{29}$ as well as some of the product brochures, ${ }^{30}$ but Rice is the most substantial in his discussion. Palliser and James appear neutrally inclined toward the system, whereas the Atlas Portland Cement Company describe it as superior to the one-piece wall, ${ }^{31}$ and Rice notes that "[ $t]$ here are numerous advantages to this system over many others now in use,"32

\footnotetext{
${ }^{27}$ Rice Concrete-Block Manufacture p 36.

${ }^{28}$ James Cyclopedia of Architecture p 29.

${ }^{29}$ Palliser Practical concrete-making pp 50-51.

${ }^{30}$ These include the Atlas Portland Cement Company published Concrete Garages pp 15-16.

${ }^{31}$ Concrete Garages p 15.

${ }^{32}$ Rice The manufacture of concrete blocks $\mathrm{p} 41$.
}

and that "the best architects and engineers were quick to recognize its points of superiority." 33

\section{Promoting the OK Block}

Shortly after his patent for a two-piece concrete block was sealed in March 1920, Anscombe wrote to Richard McVilly, the General Manager of Railways (27 March 1920), recommending his blocks for a proposed housing scheme. Anscombe identifies: strength, adaptability, protection against dampness, speed of construction, cost effectiveness, no need for painting, reduced depreciation and insurance premiums, and longer building lifespan as the advantages of his system. He notes that his construction method uses concrete "in a scientific way, no Architectural artistic effect is lost - on the contrary the same is enhanced." 34 The letter's frequent reference to "your Council" (three times) suggests that the General Manager was not the only person to receive such a letter, and that local councils in New Zealand may have also been approached. Anscombe describes the speed of block manufacture (one block per minute), and the size $\left(18^{\prime \prime} \times 9^{\prime \prime}\right.$

\footnotetext{
${ }^{33}$ Rice Concrete-Block Manufacture pp 37-38.

${ }^{34}$ Edmund Anscombe et al., letter to General Manager of Railways $\mathrm{p} 1$.
} 
[457mm x 229mm] face) and weight $(18$ pounds [8.2 kg]) of each block before offering to: "lay out an area on modern lines, plan with the greatest economy a number of houses, and prepare estimates for the same. When given the Architectural work in planning communities of houses, we make no extra charge for the use of our patented dry wall system of building."35 It is this longer description ("dry wall system of building") rather than the brand "O.K. concrete blocks", which Anscombe uses to refer to his concrete block system, possibly suggesting that this brand name had yet not been settled on.

The letter also refers to a housing scheme that Anscombe has planned (and is about to commence) for the Dunedin City Council, his office in Napier, and his intention to open a further office in Wellington due to ongoing work in the "North." In the subsequent correspondence, McVilly asked for further details, and Anscombe arranged to explain the system in person when he next visited Wellington in late April. The matter was referred to George Troup (as Officer in charge, Architectural Branch), who concluded that:

${ }^{35}$ Edmund Anscombe et al., letter to General Manager of Railways p 1. there is nothing new in their method. In fact, a similar scheme was considered by the Chief Engineer some time ago ... In my opinion their process does not contain any fresh or better features than those already known to the Department in connection with the construction of buildings in concrete. ${ }^{36}$

This verdict was conveyed to Anscombe in early July. ${ }^{37}$

At this time (mid 1920), Anscombe's appearances in the press only obliquely referred to the use of concrete in house building. In the two newspaper articles promoting his office's ideas about housing (in late July and early August 1920), there is only one inference to concrete, which stressed the need for fire-resistant houses because of safety, economy and to conserve timber. ${ }^{38}$ The point about timber scarcity is emphasised and reflected the contemporary difficulties experienced sourcing cheap building

${ }^{36}$ Troup, memorandum to General Manager.

${ }^{37}$ McVilly, letter to Anscombe (2 July 1920).

38 "Houses should be built as fire-resisting as possible.

This is a vital matter, not only from the point of view of safety and economy, but from the absolute necessity of conserving timber. There is no necessity ... to use our scant supplies of timber. Every effort should be made to conserve timber, and, whenever materials as above can be utilised at about equal cost, timber construction should not be permitted." "The Housing Problem" p 4. materials, especially timber, which, according to Ferguson, caused builders to: reduce ornamentation, ceiling heights, and corridor space, favouring open-planning and Californian Bungalow house forms, in order to save timber. ${ }^{39}$ Ferguson even noted that "[t]he government was forced ... to import steel joinery from Britain."40

Anscombe's characteristic persistence appears to have come to fruition, despite Troup's discouraging evaluation of the OK Block. By November 1920, he had convinced the Labour Department's Housing Branch to use an O.K. Block making machine to supply blocks for government housing in Miramar. ${ }^{41}$ Anscombe's involvement occurred following public controversy about the delays and cost overruns related to the building of the subdivision. Ferguson refers to the Miramar subdivision as the Reform Government's experimentation with garden suburbs, ${ }^{42}$ and notes that the Labour Department (which was where the Housing Branch was located at this time): "had experimented with new techniques, especially building in concrete, to

\footnotetext{
${ }^{39}$ Ferguson Building the New Zealand Dream $\mathrm{p} 89$.

${ }^{40}$ Ferguson Building the New Zealand Dream p 87.

${ }^{41}$ The House Everlasting pp 4, 8, 9, 12.

${ }^{42}$ Ferguson Building the New Zealand Dream $\mathrm{p} 79$
} 
improve production during the war, but these had not been particularly successful."43 Houses were rented at a significant loss. ${ }^{44}$ Difficulty in obtaining timber, the use of day labour on the Monorgan Rd houses, material wastage by "irreponsible tradesmen," 45 and inaccurate estimates ${ }^{46}$ were stated reasons. At the centre was HE Manning, the building contractor for the concrete work. From mid 1920 until the end of the year there were numerous calls for an inquiry, ${ }^{47}$ an investigation, ${ }^{48}$ a select committee on the matter, ${ }^{49}$ and a tribunal. ${ }^{50}$ The use of OK Blocks, from November 1920, dates after the initial publication of the controversy in June 1920.51 It is possible, that Anscombe, hearing of the problems occurring with the concrete contract, approached the Housing Branch, but

\footnotetext{
${ }^{43}$ Ferguson Building the New Zealand Dream p 83. ${ }^{44}$ Campbell, memorandum to The Housing Superintendent, Department of Labour (24 August 1921); "Miramar Houses: Question of Rental" p 8 ${ }^{45}$ Temple, letter to Mr. Rowley p 3.

${ }^{46}$ Campbell, memorandum to The Housing Superintendent, Department of Labour p 1.

47 "Miramar Houses: Stoppage of Work" p 7.

48 "More Speed" p 5.

49 "Miramar Houses: Questions in Parliament" p 6.

50 "More Houses" p 7.

51 "Miramar Houses: Stoppage of Work" p 7.
}

archival evidence of this is yet to be uncovered.

\section{The House Everlasting}

The following year, c.July 1921, Anscombe published, under the guise of the OK Dry Wall System Proprietary, an 18-page brochure: The House Everlasting: Homes Constructed with O.K. Concrete Building Blocks (a.k.a. The O.K. Dry Wall System of Building Construction: an Illustrated Treatise for the Enterprising Owner and Builder: Featuring this Modern System of Building and the Ideal O.K. Block-Making Machine). The brochure boasted an image of Anscombe's own house "Cintra" on the cover, described as "O.K. Residence at Andersons Bay, Dunedin, New Zealand." Its first page located the dry wall system as a tried, tested and successful system. The brochure asserts that the block was "one of the strongest, most efficient, economical, and adaptable methods of building construction yet devised," referring to current building costs, the use of Portland Cement (providing strength and durability), and the retention of "architectural artistic effect" 52 to support the claim. It was described as "light in weight, exceptionally strong, thoroughly fireproof,

52 The House Everlasting p 1. rapid in construction, and lends itself to use in every type of building structure." 53

The brochure stressed the need for good mural structure in building to ensure economy in terms of maintenance and investment. ${ }^{54}$ The economic advantages were heralded as comprehensive, and resulting from both short- and long-term savings, namely, the immediate cost benefits of: reduced labour and construction time, reduced use of cement and mortar, ease of transport and handling, and increased floor areas (c.f. brick work due to wall thinness), and longer term savings from: reduced maintenance, insurance costs, and lower depreciation costs, as well as a constant healthy temperature, due to the air cavity, which "prevents the waste of heat through radiation to the outdoors, and the conduction of cold in through the exterior walls." 55

\footnotetext{
53 The House Everlasting p 1.

54 "Your home should be so built that it will successfully withstand the ravages of time and the elements. It should be built not only as a shelter, but as an investment, and it is a GOOD INVESTMENT only when it combines beauty, practicability, and stability." The House Everlasting p 2.

${ }^{55}$ The House Everlasting p 2.
} 
The brochure then extends its initial assertion of the long track record of concrete by providing a brief history of building in concrete, referring to the Egyptian pyramids, the Great Wall of China, the Aztecs, the Romans, and Norman English cathedral foundations, before shifting its audience focus, from homeowners, to local council authorities (advocating the advantages of house building for: increasing population, contributing positively to the local economy (through increased retail customers and industry), providing additional rates revenue, and the potential of OK blocks for new industry opportunities (making use of natural resources (e.g. sand, gravel, crushed stone) as well as cinders or coke breeze)). ${ }^{56}$ The brochure then addresses builders. ${ }^{57}$ At this point the stress is on the economies of permanent buildings, acquiring an OK block plant to stimulate new business, and the suitability of OK blocks for "commercial, residential, schools, hospitals, farm buildings, and the like." 58 The brochure notes that "O.K. Blocks are recognised as the standard by which all others are measured."59 More

\footnotetext{
${ }^{56}$ The House Everlasting pp 5-6.

57 The House Everlasting pp 6,10.

${ }^{58}$ The House Everlasting pp 6, 10.

${ }^{59}$ The House Everlasting p 10.
}

specific instructions for the production of OK Blocks, from "Mixing the Concrete" to "Curing" and descriptions of "Foundations" and "Wall Thickness" and the different block types as well as "Construction Suggestions" convert this advertisement to home owners into a builders' instruction manual. ${ }^{60}$

Images throughout The House Everlasting include: narrative illustrations (e.g. houses destroyed by fire, paralleling statements regarding concrete houses as fireproof and reducing insurance premiums), ${ }^{61}$ and photographs of various houses built with $\mathrm{OK}$ blocks (including: the Government Housing Scheme in Miramar, a Residence at Otamatapau, North Otago, and a page organised into a nine-square grid of eight unnamed houses, two still under construction). ${ }^{62}$ Photographs of the OK Block manufacturing process supplement these and include an image of Messrs Stanley Bros. and Palmers' OK Plant in Hastings and another nine-square layout, illustrating OK blockmaking as "carried out by the Government Housing Department, Miramar, Wellington."63

\footnotetext{
${ }^{60}$ The House Everlasting pp 11, 12, 14, 15-16.

${ }^{61}$ The House Everlasting pp 3-4.

${ }^{62}$ The House Everlasting pp 4, 7, 12, 16.

${ }^{63}$ The House Everlasting pp 6, 8.
}

Measured drawings, including wall sections, construction details, axonometrics of single blocks and of a partially constructed wall ${ }^{64}$ complete the drawn narrative. The variety of images reflect the multiple audiences (homeowners, local authorities and builders). They sell an image of the finished house, make the process of block-making accessible, and instruct on building construction. The importance of the images is explicitly stated: "These Illustrations speak more convincingly than the strongest text we could write." ${ }^{15}$

Interspersed throughout the latter part of this narrative (from $p$ 9) are letters of recommendation from builders, homeowners and the Hastings mayor. ${ }^{66}$ These letters are all dated within the two months from early May to early July 1921, and two letters (from PH Graham, and HJ Wardell) explicitly respond

\footnotetext{
${ }^{64}$ The House Everlasting pp 13-14.

65 The House Everlasting p 7.

${ }^{66}$ These letters were from FC Gentry (manager of the government factory in Miramar, 10 May 1921), Stanley \& Palmers (builders, 23 May 1921), SB Dodge (Hastings Borough Engineers Office, 24 May 1921), George Ebbett (Past Mayor of Hastings, 20 June 1921), HJ Wardell (owner of OK house, 23 June 1921), PH Graham (Chief Housing Architect, 25 June 1921), R Williams (blocklayer, 28 June 1921), and G Wardell (owner of OK house, 9 July 1921).
} 
to an earlier Anscombe letter, suggesting all were solicited. Six letters explicitly recommend the OK Blocks, and collectively they affirm the sound, economic, and efficient construction of the OK Block houses, as well as their good insulation and temperature control. They endorse the quality, efficiency and ease of working the OK Block machine, as well as noting the ease of handling the $\mathrm{OK}$ Blocks and the system's saving of mortar.

\section{The Houses}

Houses, more than any other building type, the dominate buildings constructed with $\mathrm{OK}$ blocks. Anscombe's own house, Cintra, in 1919, was the first building constructed in OK Blocks, followed by two houses in Central and North Otago (the George Wardell house "Linburn" (1920), ${ }^{67}$ and Henry Wardell's house: "Otamatapau" (1921)). ${ }^{68}$ Anscombe recalls that, during the building of Cintra, he was visited by a Hawke's Bay firm of builders: Stanley Brothers \& Palmer, who "were so enthusiastic over the System, that they decided there and then that it was the most economical, efficient, and quickest of all known Systems, and they decided to adopt

${ }^{67}$ The House Everlasting p 10.

${ }^{68}$ The house Everlasting p 15; Anscombe "The OK Dry Wall Building Construction." it." 69 This endorsement appears to have been followed by the Dunedin council housing, which Anscombe referred to in March 1920, the Government housing in Miramar (from November 1920), and the Hastings' Mothers Rest (the blocks for this being made by Stanley Bros \& Palmer). ${ }^{70}$ Stanley Bros \& Palmer's OK enterprise in the Hawke's Bay the resulted in: the Gould House, the Gladman House (1922), ${ }^{71}$ the Rapley House (1922), ${ }^{72}$ and the Mathewson House (1925). ${ }^{73}$ Parallel with Stanley Bros \& Palmer's work in Hawke's Bay, Dunedin houses were built of OK Blocks and included: "Stoneridge" (1921), ${ }^{74}$ the Lawson house (c1923), ${ }^{75}$ and the Henry McDowell Smith House (1924). ${ }^{76}$

${ }^{69}$ Anscombe "The OK Dry Wall Building Construction." ${ }^{70}$ Harding, letter to Anscombe p 1. "Hastings Municipal Women's Rest" p 6.

${ }^{71}$ Anscombe "The OK Dry Wall Building Construction." ${ }^{72}$ Anscombe "The OK Dry Wall Building Construction." ${ }^{73}$ Wise's New Zealand Post Office Directory (1926):485; Anscombe "The OK Dry Wall Building Construction."

${ }^{74}$ Anscombe "The OK Dry Wall Building Construction." ${ }^{75}$ Stone's Otago \& Southland Commercial, Municipal, and General Directory (1923):503.

${ }^{76}$ Anscombe "The OK Dry Wall Building Construction." The Stone's Directory registered Smith living there from 1923. If this is the Bayfield house Anscombe refers to then it was built during 1924.

\section{Conclusion}

Anscombe's interest in concrete blocks at the beginning of the 1920s appears to have been short lived, but this is only part of the story. Not unlike his 1919 interest in Combined factories, which he revived in the 1940s, ${ }^{77}$ Anscombe reasserts the value of the OK Block 20 years later. At this time, he more assertively advocated concrete as the only valid material for building houses and noted the ability of the OK Block houses to survive the 1931 Hawke's Bay earthquake. He repeats his 1921 exercise of soliciting letters of recommendations from homeowners, even those who had bought an OK Block house in the interim, as well as lobbying government officials to take up the use of the block. This aspect of Anscombe's architectural practice, engaging in the design and engineering of building products, points to his understanding of architecture as comprehensively operating across the largest possible scale range. His rhetoric, apparent in the advertising brochures, which accompanied the OK Block enterprise, recalls his evaluations of architecture as necessarily pragmatic and beautiful, suggesting that he considered the design of the OK Block as an

${ }_{77}$ McCarthy "East meets West" pp 2-9. 
equally valid architectural practice as the more conventional practice of designing of buildings. 


\section{REFERENCES}

"Alphabetical List of Applicants for Letters Patent for Inventions for the Year 1921" New Zealand Patent Office Journal (24 February 1921):52.

Anscombe, Edmund "The history of the OK. Dry Wall System of Building Construction" March 1946. CA000391-3, Museum of New Zealand/Te Papa Tongarewa Collected Archives, Wellington.

Anscombe, E. "The OK Dry Wall Building Construction," CA000391, Museum of New Zealand/Te Papa Tongarewa Collected Archives, Wellington.

"Applicants for Letter Patent for Inventions for the Year 1918" New Zealand Patent Office (5 September 1918):368.

"Applicants for Letter Patent for Inventions for the Year 1918" New Zealand Patent Office (19 September 1918):395.

"Building Construction - A Patent No. 40,562" New Zealand Building Progress (March 1920):751-752.

Campbell, G.F.C., Secretary to the Treasury, memorandum to The Housing Superintendent, Department of Labour (24 August 1921) 1p. "Housing-Settlement in Monorgan Road Miramar - estimated cost of sections and houses" 1922, Archives New Zealand L 92

Concrete Garages: the fireproof home for the automobile (New York: The Atlas Portland Cement Company, [c1909]) available:

http://www.archive.org/details/concreteinconstr00atlarich

Edmund Anscombe, H. McDowell Smith and Associates letter to [R.W. McVilly] General Manager of Railways, 27 March 1920,

"Construction of Buildings and Houses in Concrete" (1908-1984) Archives New Zealand ABJP W4098 52/ 08/612 pt 1.

Ferguson, Gael Building the New Zealand Dream Palmerston North: Dunmore Press, 1994.

Gentry, F.C. letter to The Secretary, O.K. Dry Wall System Proprietary, Dunedin 10 May 1921
Graham, P.H. letter to The Secretary, O.K. Dry Wall System Proprietary, Dunedin 25 June 1921.

Harding, N.C., Town Clerk, letter to E. Anscombe (26 November 1942), CA000391-1, Museum of New Zealand/Te Papa Tongarewa Collected Archives, Wellington.

"Hastings Municipal Women's Rest, 201 Russell Street South, Hastings" New Zealand Historic Places Trust Register of Historic Places, Historic Areas, Wahi Tapu and Wahi Tapu Areas (January 2007) 26pp.

"Home Building: Address by Mr E. Anscombe" Otago Witness (21 July 1925):61.

"Home Building: Address by Mr E. Anscombe" Otago Daily Times (Friday 17 July 1925):10.

The House Everlasting: Homes Constructed with O.K. Concrete Building Blocks (a.k.a. The O.K. Dry Wall System of building construction: an illustrated treatise for the enterprising owner and builder featuring this modern system of building and the ideal O.K. block-making machine) Dunedin: O.K. Dry Wall System Proprietary, 1921.

"The Housing Problem: A workable scheme, suggested by local architects" The Evening Star (Thursday 29 July 1920):4.

"Housing Problems: the practical side" Evening Star (Tuesday 3 August 1920):7.

Isaacs, Nigel "Concrete Blocks" Build (December 2011/January 2012) 127:86-87.

James, C. Cyclopedia of Architecture, Carpentry and Building: A General Reference Work (American Technical Society, 1912) v.1. available: http://chestofbooks.com/architecture/Cyclopedia-CarpentryBuilding-4-6/index.html

McCarthy, Christine "East meets West: Edmund Anscombe's Combined Factory Building for Aotea Quay, Wellington, New Zealand" The 
Design Journal (2002) 5(3):2-9.

McVilly, Richard William letter to Edmund Anscombe (2 July 1920). "Construction of Buildings and Houses in Concrete" (1908-1984) Archives New Zealand ABJP W4098 52/ 08/612 pt 1

"Manufacturing concrete blocks - Waikeria Borstal" (1913-1921), Archives New Zealand ACGS 16225 J40W1190/267/1920-10-28

"Miramar Houses: Questions in Parliament" Evening Post (9 October 1920):6.

"Miramar Houses: Question of Rental: Explanation by Department" Evening Post (24 August 1921):8.

"Miramar Houses: Stoppage of Work" Evening Post (25 June 1920):7.

"More Houses: The Rental Law: Amending Bill Passed: Administration Discussed" Evening Post (28 October 1920):7.

"More Speed: Housing Requirements: Increased Grants to Local Bodies" Evening Post (18 September 1920):5.

Moston, Harry [Henry] E, Deputy Housing Superintendent, memorandum to The General Manager New Zealand Railways (23 July 1921) 1p. Offer by Labour Department to sell Block making machine to Department 1921, Archives New Zealand R 3 W2381 107 1916/3025/6 pt 1.

Palliser, Charles Practical concrete-block making: a simple practical treatise for the workman explaining the selection of the materials and the making of substantial concrete blocks and cement brick, together with directions for making molds and remarks on how to obtain the best architectural effects (New York: Industrial Publication Company, 1908) available: http://www.archive.org/details/practicalconcre00pallgoog

"Patents Sealed" New Zealand Patent Office Journal (11 March 1920):105.

Rapley, T.H. letter to The Secretary, O.K. Dry Wall System (7 August 1944), CA000391-1, Museum of New Zealand/Te Papa Tongarewa Collected Archives, Wellington.
"Re that all prison residence be built of concrete blocks" (1917), Archives New Zealand ACGS 16225 J40 200/1917-16-3

Rice, Harmon Howard Concrete-Block Manufacture: Processes and Machines New York: John Wiley \& Sons; London, Chapman \& Hall, Limited, 1906. Available:

http://www.archive.org/details/manufactureconc00torrgoog

Rice, Harmon Howard The manufacture of concrete blocks and their use in building construction New York: The Engineering News Publishing Company, 1905. available:

http://www.archive.org/details/concreteblockma00ricegoog

"S.P.D. System of Building Construction [pamphlet]," "Construction of Buildings and Houses in Concrete" (1908-1984) Archives New Zealand ABJP W4098 52/ 08/612 pt 1

Simpson, Pamela H., Harry J. Hunderman and Deborah Slaton "Concrete Block" Twentieth-Century Building Materials: history and conservation ed Thomas C. Jester. New York: McGraw Hill, 1995:80-85.

Stone's Otago \& Southland Commercial, Municipal, and General Directory Dunedin, N.Z.: Stone, Son \& Co., 1923.

Temple, Woburn, Deputy Housing Superintendent, letter to Mr. Rowley (14 September 1921) 5pp._Housing-Settlement in Monorgan Road Miramar - estimated cost of sections and houses, 1922, Archives New Zealand L 92

Thornton, Geoffrey Cast in Concrete: concrete construction in New Zealand 1850-1939 Auckland: Reed Books, 1996.

Troup, George A. to General Manager, 21 June 1920, "Construction of Buildings and Houses in Concrete" (1908-1984) Archives New Zealand ABJP W4098 52/ 08/612 pt 1.

Wise's New Zealand Post Office Directory Dunedin: H. Wise \& Co, NZ Ltd, 1926. 